\title{
CONSIDERAÇÕES SOBRE O INSTITUCIONALISMO DE MAURICE HAURIOU: BASES FILOSÓFICAS E VERIFICAÇÃO HISTÓRICA
}

\section{CONSIDERATIONS ABOUT THE INSTITUTIONALISM OF MAURICE HAURIOU: PHILOSOPHICAL BASES AND HISTORICAL VERIFICATION}

Cláudio de Cicco $^{1}$

\section{RESUMO}

Objetivo: O presente artigo visa relembrar a produção de um autor que,não se sabe bem por que, anda meio esquecido em nosso país: Maurice Hauriou. Tirou-o do imerecido ostracismo o saudoso Prof.Miguel Reale em seus Fundamentos do Direito, publicado em $4^{\text {a }}$ edição pela Editora Migalhas,em 2014. Com efeito, trata-se de pensador e jurista francês que trouxe para o cenário jurídico o que considera o máximo problema da Filosofia do Direito: a passagem da situação de fato para o nível imperativo da norma jurídica. Terçaram armas a esse respeito juristas como Émile Durkheim,o criador da Sociologia Jurídica, os neokantianos Rudolf Stammler, Georg Jellinek, Gustav Radbruch, pai do culturalismo jurídico.

Método: A solução de Maurice Hauriou mostra ser mais inteligente, pois integra os fatos sociais em torno de um objetivo racionalmente aceito como a busca da ordem social mais justa, sem considerá-la uma quimera, sem cair em hipóteses arriscadas como ponto de partida, nem reduzir o direito apenas à dimensão normativa, fática ou axiológica. Veremos que não se trata de caminho inexplorado até então, mas da retomada da crítica contra o racionalismo que, de Descartes a Kant, empolgou a intelectualidade europeia e cujo maior representante no campo político foi Jean-Jacques Rousseau, com enorme repercussão no campo jurídico, tendente a um voluntarismo, transferido da vontade do príncipe para a vontade da multidão, tornando-se secundário o aspecto justiça de uma norma jurídica,de acordo com o cínico aforisma: "Potestas,non sapientia,facit legem"= é o poder, e não a sabedoria que faz a lei."

Resultados: A crítica veio da Escola Histórica do Direito de Frederico Carlos von Savigny, mas esta, ainda que acertadamente lembrasse a importância da história das nações na formação do direito, soava como nostálgica e mesmo romântica,como defesa do passado para condenar a Revolução Liberal. Não é esta a filosofia de Maurice Hauriou, que se volta para a história com olhar evolucionista e dinâmico na linha de Henri Bergson, por isso considerado por Miguel Reale como o "Bergson da Ciência do Direito". E Bergson, como se sabe, foi uma reação contra o idealismo kantiano, mostrando pontos de contato entre as ciências humanas e as ciências naturais, no seu clássico livro "L'Évolution Créatrice"(A Evolução Criadora) que logrou ser

\footnotetext{
${ }^{1}$ Bacharel em Ciências Jurídicas e sociais pela USP; Mestre em Ciências da Comunicação pela USP;Doutor em Teoria Geral do estado pela PUCSP;ILivre-docente em Filosofia do Direito pela USP. Lecionou História e Filosofia do Direito na USP, nos cursos de Graduação e Pós-Graduação. Leciona Filosofia do Direito e Teoria Geral do Direito na PUCSP, nos cursos de Graduação e Pós-Graduação. Pontifícia Universidade Católica de São Paulo PUC-SP - Brasil. Lattes: http://lattes.cnpq.br/9189782952230177 E-mail: claudiodecicco@uol.com.br
} 
laureada com o Prêmio Nobel.

Conclusões finais: Temos que frisar que a grande contribuição de Hauriou é a idéia de instituição. O direito nasce nas instituições de que o Estado é uma espécie importantíssima, mas não a única. No momento em que se discute em nosso país o gigantismo do Estado e se deseja abrir cada vez mais espaço para a sociedade civil, formada por pessoas com dignidade própria, vinculadas por um ideal comum em instituições representativas, este artigo pode ser portador de alguma luz, para basear toda uma revisão de conceitos consagrados dogmaticamente, sem exame crítico algum.

Ideias-chave: Instituição-História-Justiça-Maurice Hauriou-Lei

\section{SUMMARY}

The present article try to remember the production of one author that-we don't know why- is amost forgotten in our country: Maurice Hauriou. The deeply missed Professor Miguel Reale, take him off from that undeserved oblivion in his recently republished book "Fundamentos do Direito"(Editora Migalhas,2014). In fact, it is a question about one French thinker and jurist that brought to the juridical scenery what he thinks as the most important problem of juridical philosophy: the passage from the situation of fact to the imperative level of law. Many authors have fight about this matter,like Emile Durkheim, the father of Juridical Sociology, the followers of Kant Rudolf Stammler, Georg Jellinek, Gustav Radbruch, the father of juridical culturalism.

The solution proposed by Maurice Hauriou displays more clever , constituting social facts with a rational objective search for a more just social order, without considering that like a dream, without falling in a methaphysical hypothesis about the point of departure, without decrease the right to the normative, factualy or axiological dimension. We shall see that it is not one unexplored way, but the retake of the critics against the rationalism that, from Descartes to Kant,excited the European mind, and whose greatest representative was Jean-Jacques Rousseau, with enormous repercussion in the juridical field, having a tendency on self-willed point of view, transferred from the willof the prince to the will of the multitude, returning the just as a secondary aspect of the law, following the cynical remark "the law is made by the power, not by the wisdom."

Criticism comes from the Historical School of Law by Friederich von Savigny, but that - who correctly remembered the amount of the history of nations to the creation of law -was considered as a nostalgia and romantic defense of the past, to condemn the Liberal Revolution. That is not the philosophy of Maurice Hauriou, who looks to the history with one evolutionary and dynamic eye, in the line of Henri Bergson, for this reason considered by Miguel Reale as "the Begson of the science of law".And Bergson, as we know, was a reaction against the idealism of Kant, showing points of connection between human sciences and natural knowledge, in his classic work "The Creative Evolution”, honoured with Nobel award.

We must emphasize the greatest contribution of Maurice Hauriou was the idea of institution. The laws are born in the institutions and the State is not the only.In that moment when we discuss 
the State as a giant, in our country, and we want to increase the participation of civil society, with persons with own dignity, linked by a common ideal in representative institutions, this article is able to produce some light to base one complete review of sacred dogmatic conceptions, without any critical examination.

Key-words: Institution-History-Justice-Maurice Hauriou-Law

\section{INTRODUÇÃO}

O monismo de Hans Kelsen, que, no início do século passado, considerava jurídica só a norma emanada do Estado, se, de um lado, encontrou enorme acolhida no mundo acadêmico, pois devolvia inegavelmente à Ciência do Direito sua autonomia, comprometida pelas tendências sociológicas de um Léon Duguit e de um Émile Durkheim, vinha de encontro a uma forte corrente de tendência pluralista, a qual via no Estado talvez a mais importante instituição, mas não a única capaz de produzir normas jurídicas, convivendo com outras instituições.

O jurista francês Maurice Hauriou (1856-1929) chegou a dizer: "O problema fundamental do Direito é a transformação da situação de fato em situação de direito.” E isto se verifica quando há um encontro entre operações jurídicas repetidas de governo e de administração, ligadas por procedimentos, de modo a ter uma duração consistente na trama mais leve das relações jurídicas passageiras."2

Ora, não pode surgir uma instituição sem uma idéia diretriz, ou "3idéia de uma obra a ser realizada para vantagem do grupo social, sendo tal idéia o elemento mais importante da instituição."

No seu modo de ver, foi uma idéia diretiva que fundamentou uma instituição jurídica de direito privado, como uma empresa. Não são as normas que criam a empresa, mas a idéia de constituí-la, por pessoas subjetivamente interessadas em ter algum lucro. Quando a empresa é criada objetivamente para se inserir de modo durável na realidade social, a norma é instrumento adequado para tanto. Logo o papel da norma jurídica é insubstituível, mas não é dela que se origina a instituição.

\footnotetext{
${ }^{2}$ Maurice Hauriou. Teoria dell'Istituzione e della Fondazione, pag.13-14.

${ }^{3}$ Idem,ibidem, pag. 17.
} 
Comenta Miguel Reale que a teoria de Maurice Hauriou é uma tentativa bem sucedida de superar a dicotomia subjetivismo -objetivismo (assentimento individual ou consciência coletiva), na solução do problema da fundamentação da validade do Direito. ${ }^{4}$

\section{A TEORIA DA INSTITUIÇÃO DE MAURICE HAURIOU}

“Se nós queremos escapar desses dois erros, subjetivismo e objetivismo, é preciso retornar a essa verdade de experiência comum, que tudo não é bom no indivíduo, que as sociedades organizadas tem necessidade de ser submetidas à mesma lei moral que o indivíduo, é preciso situarmos a lei moral fora da sociedade e fora do indivíduo, é preciso que ela seja uma realidade exterior à qual a espécie humana se tenha adaptado mais ou menos completamente."

"Por esse magnetismo espiritual o homem é atraído para o bem como a agulha da bússola pelo polo."

"Essa diferença na urgência dos fins conduz o sociólogo a essa conclusão que a ordem social é um elemento das sociedades mais primordial que a justiça. É preciso se resignar com esta constatação. A ordem social estabelecida é o que nos separa da catástrofe; na maioria os homens dos países civilizados preferem suportar uma certa dose de injustiça antes que correr o risco da catástrofe. A ordem social representa o mínimo de existência, e a justiça social é um luxo do qual em certa medida se pode prescindir."

“...é o fenômeno histórico da instituição que beneficiou e humanizou progressivamente as organizações sociais, que tornou o senhorio feudal mais humano no século doze que no século décimo e o patronato industrial mais humano no século vinte que no dezenove."

"Há beleza na maquete(modelo), ainda que ela seja o primeiro jato, mas retoques do artista são necessários para lhe infundir ainda mais beleza,retoques sucessivos devem lhe incorporar sempre mais.

"E entretanto, existe um limite: os retoques não devem comprometer o equilíbrio estático da construção. A ordem social democrática realiza mais justiça social que a aristocrática, mas também a experiência a denuncia como mais frágil, porque a igualdade na liberdade compromete seu equilíbrio estático, que se faz na base de poder e autoridade.”

\footnotetext{
${ }^{4}$ Miguel Reale, Fundamentos do Direito, pag. 291.
} 
“...as instituições vivem de uma vida ao mesmo tempo objetiva e subjetiva, graças a operações jurídicas de governo e de administração repetidas e, aliás, ligadas por procedimentos. Assim, elas ocupam juridicamente a duração e sua cátedra sólida se cruza com a trama mais leve das relações jurídicas passageiras."

“A idéia tornaria seus próprios adeptos mais próximos no grupo dos interessados na realização do empreendimento. Mas mesmo nesse grupo ela permanece, ordinariamente, no estado objetivo, no subconsciente. Passará depois gradualmente para o estado subjetivo com as manifestações da vontade consciente, mas isso acontecerá, ao menos na aparência, de modo descontínuo, enquanto a ação da idéia objetiva, no subconsciente da memória, será contínua.

“E a idéia ? A idéia está e volta a estar no seu céu por força própria, misteriosa. A idéia não tem criadores, tem somente quem as encontra...

Assim a unificação tentada por esta teoria, do particular com o universal, do sujeito com o objeto, não se pode dizer que foi conseguida."

"A regra de direito não emana dos fatos sociais da mesma maneira que as leis físicas emanam dos fenômenos físicos; ela é sempre obra de um poder que, em certa medida, se impõe às forças sociais; convém desconfiar de todos os sistemas que afirmam o império do direito. $\mathrm{O}$ direito não reina por si mesmo. Por trás da regra de direito é preciso procurar o poder que a sanciona."

"Se toda instituição engendra uma regra de direito, em compensação nem toda regra de direito é institucional."

"O direito também é norma, mas antes de ser norma, é organização ou corpo social, e é isso que lhe comunica, como a um seu produto ou derivação, a natureza jurídica, e não o contrário."

Em outras palavras: "O direito, antes de ser norma e antes de se referir a uma relação ou a uma série de relações sociais, é organização, estrutura e instituição da própria sociedade.” Esta ideia será retomada por Santi Romano.

\section{A NOÇÃO DE INSTITUIÇÃO NA BASE DO PENSAMENTO JURÍDICO DA ESCOLA HISTÓRICA DO DIREITO NA ALEMANHA E NA SAVOIA}

Segundo nosso modo de ver, o jurista francês Maurice Hauriou (1856-1929) retomou estes postulados de Savigny, Gierke e De Maistre quando escreveu "La Science Sociale Traditionelle” em 1896 e sobretudo, em 1898, “La Personnalité comme Élément de la Réalité 
Sociale" pois queria descobrir o fundamento da validade da lei jurídica, desconfiando da simples positivação pelo Estado.

"Savigny, Gierke De Maistre reabilitaram o passado e nele procuram os germens das instituições do presente. As normas e as instituições jurídicas readquirem valor em proporção de sua antiguidade. (...) Única e verdadeira geradora do Direito é a alma coletiva que se afirma nas instituições jurídicas, se perpetua nas tradições, se desenvolve e se encontra nos legisladores e nos juristas como seus fiéis e autorizados intérpretes"5

Podemos ver sem dificuldade a afinidade do institucionalismo de Maurice Hauriou com as pesquisas da Escola Histórica.

Causou-nos satisfação notar que o historiador da jusfilosofia Guido Fassò, em sua obra Storia della Filosofia del Diritto, lecionava:"Com alguma afinidade com Otto Gierke, Maurice Hauriou concebe uma organização social mais alta, que possui concomitantemente a soberania e o poder: a instituição, órgão dotado de um poder dominante, colocado a serviço dos fins que interessam ao grupo social, por meio de uma atividade coordenada correspondente à do conjunto do grupo. Não só o Estado é uma instituição, mas todas elas são capazes de criar norma jurídica, enquanto encarnação do direito pelo fato mesmo de existirem. (vol.3º ${ }^{\circ}$ pag. $256,257)$.

Lembremos que, contra a tese do contrato inicial, ergueu-se a "Escola Histórica do Direito e do Estado" de Oto von Gierke e Frederico Carlos von Savigny, onde encontramos fundamento para o institucionalismo pluralista.

Savigny enfatiza o relacionamento primário da intuição do jurídico não à regra genérica e abstrata, mas aos 'institutos de direito' (Rechtsinstitute), que expressam as 'relações vitais' (Lebensverhältnisse) típicas e concretas. Os ‘institutos’ são visualizados como uma totalidade de natureza orgânica, um conjunto vivo de elementos em constante desenvolvimento. É a partir deles que a regra jurídica é extraída mediante um processo indutivo, manifestando o sistema, assim explicitado, uma contingência radical e irretorquível"6.

Savigny dissera em 1810, no "Manifesto da Escola Histórica do Direito", que ao jurista cabe revelar o "espírito do povo", (hoje se diria: a sua cultura), nas leis que regerão esse mesmo povo.

Eis por que a Escola Histórica se coloca contra os postulados da Escola Clássica do

5 Gioele Solari, Socialismo e Diritto Privato, Milano, Ed. Giuffrè, 1980, p. 55.

6 Tercio Sampaio Ferraz Jr., A Ciência do Direito, São Paulo, Ed. Atlas, 1977, p. 27-30. 
Direito Natural dos séculos XVII e XVIII, pois, enquanto os jusnaturalistas como Wolf e Pufendorf consideram que o parâmetro da justeza e da justiça só pode ser a racionalidade do sistema das normas jurídicas, de validade universal, restaurando antiquíssimo ensinamento estoico, para a Escola de Savigny esse critério deve ser buscado na história das instituições, a qual varia de povo para povo, e por isso mesmo não pode ser a mesma para todos os países, no que Savigny se choca com o pensamento iluminista, cosmopolita e universalista.

Ao "Espírito das Leis" de Charles Sécondat de la Brède-Montesquieu, Savigny contrapõe o "Espírito do Povo" (Volksgeist).

Segundo sua biografia intelectual, a formação saviniana foi kantiana, mas por ela não se deixou influenciar muito, a ponto de aderir a seu formalismo. Von Savigny aprendeu, sem dúvida, com Emanuel Kant a ideia de autonomia da realidade empírica e a noção de relativismo do saber fenomênico. Em tais postulados kantianos, o empirismo em geral e o historicismo em particular, acharam uma razão de ser.

Ao propor um estudo das fontes do direito, que no fundo era o direito romano " $d a$ recepção", que já pressupunha a aceitação do Sacro Império como fato consumado, marca histórica indelével do mundo germânico, Savigny estava longe de supor que grande movimento, que imenso programa de ideias estava pondo em movimento, embora não correspondendo aos anseios de uma elite burguesa , a qual se inclinava para Gottlieb Fichte e demais nacionalistas defensores de uma Alemanha unificada, em que haveria menos taxas aduaneiras a cobrar e menos cambistas a suportar.

Savigny começava por valorizar as fontes medievais do direito germânico visigótico com um estudo sistemático das fontes do direito romano da "recepção"7, mas ao mesmo tempo dava ensejo à discussão de uma problemática esquecida desde Gian-Battista Vico: a historicidade do direito e da cultura, perdida de vista, ofuscada pelo Século das Luzes e seu cosmopolitismo.

$\mathrm{Na}$ Escola Histórica do Direito, Savigny, portanto, ainda aceita o direito romano " $d a$ recepção"como recebido e incorporado ao direito germânico.

Mais radical e coerente com a proposta da Escola Histórica foi o jurista Otto Friedrich von Gierke o qual, na linha inaugurada por seu mestre Georg Beseler, desenvolveu a concepção de Direito Corporativo representando uma linha germanista mais autêntica

\footnotetext{
${ }^{7}$ Gioele Solari, Storicismo e Ditto Privato, p. 27 e s.
} 
da Escola Histórica do Direito. Mostrou que as associações seriam organismos vivos, quer dizer, entidades psíquicas reais e, assim, não assimiláveis à individualidade de seus membros.

Seriam pois as associações entes reais, organismos, dotadas de vida própria. Por isso von Gierke é citado como um dos criadores do conceito de "pessoa jurídica", perante um racionalismo jurídico incapaz de entender o que ultrapasse o conceito de pessoa física, individual. Aberto à compreensão de comunidade de pessoas, von Gierke, desenvolvendo o conceito de propriedade de acordo com a tradição jurídica germânica, foi de encontro à consagrada concepção individualista de propriedade vinda do Direito Romano, que a define como "jus utendi,fruendi et abuttendi(latim=direito de usar, fruir e abusar(sic!)" da coisa.

Debruçando-se sobre o direito medieval escreve a obra pioneira: "Teorias Políticas da Idade Média" que afasta as criticas radicais do Renascimento e do Iluminsmo, para tentar estudar uma sociedade com cosmovisão diferente da contemporânea, quer liberal, quer socialista, por ser "corporativa".

O que seria uma visão "corporativa" - e portanto pluralista - da sociedade e do Estado ?

Vejamos seu mais conhecido intérprete, Joseph De Maistre, italiano de cultura francesa, senador na corte de Savoia-Piemonte e depois embaixador da Savoia em São Petersburgo.

"La Politique est comme la Physique, il n'y en a qu'une de bonne: l'experimentale."= A Política é como a Física, não há senão uma boa: a experimental)

Mas, poder-se-ia perguntar, onde está o campo de experiência da Política? Respondenos o mesmo autor: "L'Histoire est la politique experimentale", a História é a política experimental.

Vale dizer: não há instituições políticas que correspondam aos anseios dos povos que vivem sob sua tutela senão as consagradas pela história; o contrário também é verdade: as instituições que colidem com as legítimas aspirações nacionais mostram, historicamente, os frutos nefastos que nenhuma argúcia de argumentação conseguirá ocultar.

Tratava-se, evidentemente, de uma reação ao pretenso universalismo das ideias de 1789.

Ironicamente, dizia De Maistre: "Il n'y a point d'homme dans le monde. J'ai vu des Français, des Italiens, des Russes etc. Je sais même, grâce a Montesquieu, qu'on peut être Persan. Mais, quant à l'homme je déclare de ne l'avoir recontre de ma vie. S'il existe, c'est bien a mon insu"8. (Não há homem no mundo. Vi franceses, italianos, russos etc. Sei mesmo, graças a Montesquieu, que existem persas. Mas quanto ao homem declaro nunca tê-lo encontrado em

\footnotetext{
${ }^{8}$ Joseph De Maistre, Considérations sur la France, 20. ed., Paris, Ed. Vitte, 1924, p. 74.
} 
minha vida. Se ele existe, é sem que eu saiba.) Realmente, o "homem" sem características nacionais, regionais próprias não existe. É fruto de uma abstração. O que existe é o homem in concreto, com sua língua, sua nacionalidade, sua tradição cultural própria.

Pois bem, em nome de pretensas "características" do "homem" se sacrificaram as reais e evidentes características dos povos e das nações, rumo à sociedade padronizada e massificada em que vivemos cada dia mais imersos.

É lógico que, as características nacionais sendo preteridas, não tinham sentido algum os grupos sociais. O "homem" abstrato é o indivíduo, isolado, que não se liga a outros indivíduos organicamente, apenas se justapõe mecanicamente. Substituiu-se uma sociedade de povos diferenciados com vida própria por uma multidão amorfa ou massa.

No início do século XIX, 50 anos antes de Marx, surgiu uma profunda análise crítica da construção doutrinária da ordem jurídica liberal, ao nível dos princípios básicos e de sua aplicação nas várias codificações, empreendida pelos autores católicos Joseph De Maistre e Louis de Bonald em suas obras Réflexions dur la France e Théorie Du Pouvoir Politique et Réligieux, respectivamente.

Pode-se facilmente notar a aversão de quem escreve às doutrinas que analisa, e, pelo contrário, a muita simpatia com que os autores passam em revista todas as vantagens trazidas à Europa pela civilização cristã, que se tentara reduzir a "uma Idade de trevas" com o Iluminismo e com a Revolução Francesa.

Desejando um retorno ao pensamento medieval de Santo Agostinho e de São Tomás de Aquino, sobretudo no que diz respeito à autoridade do papa e dos reis e à obrigatoriedade da moral bíblica e católica de antes da Reforma, defendida no Concílio de Trento e divulgada pelos jesuítas até mesmo em longínquas colônias, Joseph De Maistre, desde as Lettres d'un Royaliste Savoisien até as Soirées de Saint-Pétersbourg, e Louis de Bonald, da Théorie du Pouvoir Politique et Réligieux aos Essais sur l'Éducation, opõem-se radicalmente ao racionalismo inaugurado por Descartes, e que dera como resultado último o contratualismo de Rousseau.

O Conde Joseph De Maistre, bastante conhecido pelo seu livro clássico Les Soirées de Saint-Pétersbourg, com a mesma precisão da mise au point, em suas obras Considérations sur la France e Étude sur la Souveraineté, refuta o contratualismo de Rousseau e propõe uma concepção orgânica do Estado, que, vitoriosa, afastaria para sempre o Leviatã dos 
totalitarismos9.

Foi Jean-Jacques Rousseau, como já vimos, quem abriu caminho para uma concepção abstrata do Estado, produto de elucubrações "a priori”, e que, exatamente por desprezar os dados da história e o acervo cultural que forma a Nação, lançou a idéia de "volonté générale" como fonte do direito. Sem discutirmos aqui o alcance político da idéia, que fundamentou a soberania nacional da Revolução Francesa e levou a burguesia ao poder, ao mesmo tempo facilitou- ao proclamar "entre o indivíduo eo Estado não pode haver intermediários-, o regime totalitário, Leviatã, que absorve os grupos sociais e os indivíduos, transformando um povo em uma "massa".

Para Joseph De Maistre, a sociedade surge natural e organicamente10:

“Toda questão sobre a natureza do homem deve ser resolvida pela História. O filósofo que quiser nos provar, por raciocínio a priori o que é o homem, substitui razões de conveniência e suas próprias decisões à experiência e à vontade do Criador.

"A História nos mostra os homens vivendo, constantemente, reunidos em sociedades, regidas por uma autoridade soberana. Logo, a sociedade não é obra do homem. Rousseau imagina um povo 'no estado natural', deliberando sobre as vantagens e desvantagens do 'estado social', resolvendo passar daquele para este. Que faziam os homens antes dessa 'convenção nacional' em que resolveram aceitar um chefe? Viviam sem leis, nem governo? Desde quando?

"Erro capital é representar o estado social como escolha fundada no consentimento dos homens, em deliberação e contrato primitivo. Isto é utópico.

“O ‘estado de natureza’ é então o de ser hoje o que o homem sempre foi: um ser sociável; todos os anais do mundo estabelecem esta verdade"11.

“Admito, para argumentar, que me provem que um selvagem tem mais felicidade e menos vícios que um homem civilizado: pode-se daí concluir que este é um ser decaído e mais longe do 'estado de natureza' que o primeiro? Claro que não. Seria o mesmo pretender que a natureza do homem é permanecer criança, pois nessa época da vida ele está isento de vícios e preocupações da idade madura".

Estabelecida a origem natural da sociedade, De Maistre nos fala agora da necessidade da autoridade para o seu funcionamento:

\footnotetext{
${ }^{9}$ Realmente,o Estado totalitário se torna mais possível de se concretizar onde forem destruídos os corpos sociais intermediários entre o indivíduo e o Estado, como a família, a escola particular, a empresa privada, a associação profissional autônoma, a igreja, o clube,etc.

${ }^{11}$ Joseph De Maistre, Étude sur la Souveraineté, 4. ed., Lyon, Liv. E. Vitte, 1924, p. 96 e s.
} 
"É tão impossível imaginar uma sociedade sem chefe, como um enxame de abelhas sem rainha, pois o enxame existe dessa forma, ou deixa de existir. A sociedade e a soberania nasceram, pois, juntamente: é impossível separar as duas ideias"12.

Partindo de premissas contrárias, Rousseau chega a admitir que a sociedade e a soberania do Estado são meras concessões do povo, podendo, evidentemente, ser suprimidas ao capricho dos "contratantes", que são os cidadãos. Por mais que o filósofo de Genebra ressalve que "a ordem social é um direito sagrado que serve de base a todos os outros", é ele mesmo que admite: "entretanto não vem esse direito da natureza, pois funda-se em convenções"13.

Para nossos leitores aquilatarem ao que isso nos conduz, vejamos o que nos diz o Prof. José Pedro Galvão de Sousa:

"Rousseau é, na verdade, uma expressão típica da atitude mental abstracionista tão difundida no século XVIII. A organização concebida nas páginas do Contrato Social corresponde plenamente à ideia do Estado totalitário. Mas o pressuposto sociológico ou o esquema da sociedade política segundo o liberalismo radical — o Estado sem sociedades parciais e tendo diante de si o povo constituído por indivíduos soltos — ali se delineia”14.

Mas prossegue De Maistre:

“As próprias concessões de um chefe foram sempre precedidas por um estado de coisas que as provocou e que do chefe não dependem.

"Os direitos do povo, propriamente ditos, originam-se frequentemente de concessões do soberano; mas os direitos do soberano, enquanto chefe do Estado, não resultam de concessão, ao menos no que respeita aos direitos essenciais e constitutivos da autoridade.

"Embora as leis escritas não sejam senão declarações de direitos anteriores, entretanto nem tudo pode ser escrito. Quanto mais se escreve, mais a instituição é fraca e a razão é clara. As leis não passam de declarações de direitos e os direitos não se declaram, exceto quando atacados; de sorte que a multiplicidade de leis escritas não prova senão a mul-tiplicidade dos choques e o perigo de uma destruição.

"Nunca uma nação tentou desenvolver eficazmente, por meio de leis fundamentais escritas, outros direitos que aqueles que existiam em sua constituição natural.

\footnotetext{
${ }^{12}$ Ibid., p. 103.

${ }^{13}$ Contrato Social, cap. I.

${ }^{14}$ José Pedro Galvão de Sousa, A Historicidade do Direito e a Elaboração Legislativa, São Paulo, edição do autor, 1970 , p. 57-8.
} 
"Uma assembleia qualquer de homens não pode constituir uma nação e provar esta proposição com detalhe (depois de tudo o que eu já disse), parece-me que seria faltar ao respeito para com os que sabem, e honrar em demasia os que não sabem"15.

A Revolução Francesa, em sentido contrário, e fiel a seu corifeu Rousseau, criou o Estado anorgânico, composto de indivíduos, não de grupos. E isto vem até a democracia liberal de nossos dias.

Em A Historicidade do Direito e a Elaboração Legislativa, o Prof. José Pedro Galvão de Sousa mostra o resultado: a tensão entre a norma e a realidade do direito constitucional:

"As constituições vinham a ser assim obra de homens instruídos ao sabor de influências estrangeiras, desenraizados de sua terra e de sua gente e vinculados aos interesses da classe social dominante. Eram as 'elites marginais'16.

"Aliás, nas democracias modernas, a realidade dos grupos mais ou menos ocultos e do poder econômico é a fonte da 'contra-Cconstituição', enquanto o princípio da origem popular do governo é a expressão teórica da constituição formal.

"A influência humana não se estende além do desenvolvimento dos direitos existentes, mas que estavam sendo contestados ou ignorados; se os imprudentes ultrapassam os limites das reformas temerárias, a nação perde o que tinha, sem atingir o que pretende.

"Mesmo os legisladores carismáticos não fazem senão reunir elementos preexistentes nos costumes e caráter dos povos.

"Salutares tendências do pensamento contemporâneo indicam uma volta ao sentido de historicidade do direito, ao mesmo tempo em que a sociedade, por seus grupos naturais históricos, reage contra a tirania absorvente dos totalitarismos hodiernos"17.

Os resultados de tal valorização estão patenteados pela história: a organicidade da Idade Média deveu-se em grande parte ao respeito ao princípio de subsidiariedade, isto é, os grupos menores devem realizar tudo o que estiver em sua esfera de atuação, sendo subsidiariamente auxiliados pelos grupos maiores, no que escapar a suas atribuições.

\section{EXEMPLIFICAÇÃO DO PAPEL DA INSTITUIÇÃO NA ANTIGUIDADE GRÉCO-}

\footnotetext{
15 Joseph De Maistre, Considérations sur la France, Lyon, Liv. Ed. Vitte, 1924.

${ }^{16}$ Galvão de Sousa, José Pedro. A Historicidade do Direito e a Elaboração Legislativa, São Paulo, edição do autor (tese de livre-docência na Faculdade de Direito da USP), 1970.

${ }^{17}$ José Pedro Galvão de Sousa, op. cit., p. 115.
} 


\section{ROMANA}

Fustel de Coulanges, na obra ainda clássica La Cité Antique, salienta a importância do culto dos antepassados na sociedade tanto latina como helênica, em seus primórdios, para mostrar que o poder paterno é uma das peças fundamentais para entender a antiga instituição da família, da propriedade, da herança, da autoridade, de que permaneceram traços mesmo em institutos romanos da Época Clássica.

Fustel de Coulanges observa que "a família não recebeu suas leis da cidade. Se tivesse sido a cidade a estabelecer o direito privado, teria provavelmente elaborado algo diverso, teria regulado de acordo com outros princípios o direito de propriedade e o direito de sucessão, pois não era de seu interesse que a terra fosse inalienável e o patrimônio fosse indivisível.

"A lei que permite ao pai vender ou até mesmo tirar a vida de seu filho, lei que encontramos tanto na Grécia como em Roma, não foi imaginada pela Cidade. Ela teria antes dito ao pai: 'A vida de tua mulher e de teu filho não te pertencem e nem a sua liberdade; eu os protegerei mesmo contra ti; não serás tu que os julgarás, que os executarás se eles se tornarem culpados: eu serei seu único juiz'.

"Se a Cidade não fala assim é porque ela não pode, pois o Direito Privado existia antes dela. Quando ela começou a estabelecer suas leis por escrito, já encontrou esse Direito estabelecido, vivo, enraizado nos costumes, forte através de uma adesão universal. Ela o aceitou, por não poder agir de outro modo, e não ousou modificá-lo senão com o correr do tempo.

"O Direito antigo não é obra de um legislador, mas antes se impôs ao legislador. Foi na família que ele nasceu. Saiu espontaneamente e todo formado dos antigos princípios que o constituíam. Decorreu de crenças religiosas que eram universalmente admitidas, na era primitiva de tais povos e que exerciam um império sobre suas inteligências e sobre suas vontades"18.

Diz ainda Fustel de Coulanges: "A religião doméstica está de acordo com a natureza, ela afirma que o pai será o chefe do culto, e que o filho deverá somente ajudá-lo em suas funções sagradas. Mas a natureza não exige esta subordinação senão durante um certo número de anos, a religião exige mais. A natureza dá ao filho uma maioridade, que a religião não lhe concede.

"De acordo com antigos princípios o lar é indivisível e a propriedade é como ele, os

18 Numa Dénis Fustel de Coulanges, La Cité Antique, Paris: Hachette .9. ed., , 1881, p. 93. 
irmãos não se separam pela morte do pai, com muito maior razão não podem se separar dele durante a vida. No rigor do direito primitivo os filhos continuam unidos ao lar paterno e, assim sendo, ficam submetidos à sua autoridade. Enquanto ele viver, os filhos são considerados menores"19.

É, pois, mais exato falar em "pátrio poder" do que em "poder paterno". "Paterno" é adjetivo que etimologicamente se reserva para qualificação de parentesco: avô paterno, lado paterno etc. Já "pátrio" exprime a ideia de hierarquia e de estirpe: patriciado, gens patrícias, e, como lembra La Cité Antique: "Platão diz que o parentesco é a comunidade dos mesmos deuses domésticos. Plutarco define dois irmãos como sendo dois homens que têm o dever de fazer os mesmos sacrifícios domésticos. O princípio do parentesco não era o nascimento, era o culto. A agnação era o parentesco como ficara estabelecido pela religião no princípio.

“À medida que a antiga religião se enfraqueceu, a voz do sangue passou a falar mais alto, e o parentesco por nascimento foi reconhecido pelo Direito: os romanos chamaram de 'cognatio' esta espécie de parentesco, que era absolutamente independente das regras da religião doméstica"20. E qual o fundamento do poder do pai, na tradição mais antiga? "Tinha por princípio e por condição o culto doméstico. O filho nascido do concubinato não estava colocado sob a autoridade do pai. Entre o pai e ele não existia comunidade religiosa, não havia, pois, nada que conferisse a um, autoridade, a outro, obediência. A paternidade não era por si só suficiente para conferir direitos de pai'”21.

Que direitos eram esses?

"As leis gregas e romanas reconheceram esse poder ilimitado do pai, como dele o revestira a religião, nos primórdios.

"Os vários direitos que as leis lhe conferiam podem ser catalogados em três categorias, segundo se considera o pai de família como chefe religioso, como senhor da propriedade ou como juiz. O pai é o chefe supremo da religião doméstica, dirige todas as cerimônias do culto, e, por consequência, é o responsável pela perpetuidade do culto e da família. Tudo o que se relaciona com essa perpetuidade, que é seu primeiro dever e cuidado, depende apenas dele. Daí deriva uma série de direitos: direito de reconhecer a criança no ato do nascimento ou de rejeitála. Esse direito é atribuído ao pai, tanto pelas leis gregas como pelas leis romanas (Heródoto, I,

\footnotetext{
19 Fustel de Coulanges, op.cit. p. 96

20 Ibid., p. 58.

21 Ibid., p. 96.
} 
59. Plutarco, Alcibíades, 23. Agesilau, 3).

“Por mais bárbaro que nos pareça, não está em contradição com os princípios básicos da família (antiga). A filiação, mesmo se incontestada, não basta para ingressar no círculo da família, é necessário o consentimento do chefe e a iniciação no culto. Enquanto a criança não for associada à religião doméstica, nada representa para o pai. Direito de repudiar a mulher, quer em caso de esterilidade, porque a família não deve se extinguir, quer em caso de adultério, porque a família e a descendência devem ficar isentas de toda e qualquer alteração. Direito de ceder a filha em casamento, cedendo a outro o poder que tem sobre ela. Direito de ceder o filho em casamento, pois o casamento do filho interessa à perpetuação da família. Direito de emancipar, isto é, de excluir um filho da família e do culto. Direito de adotar, isto é, de introduzir um estranho junto ao culto do lar doméstico. Direito de designar, ao morrer, um tutor para a mulher e para os filhos. (...) O filho não possuía coisa alguma, nenhuma doação feita por ele era válida, pela mesma razão que nada possuía de próprio, não podia adquirir coisa alguma, os frutos de seu trabalho, os lucros de seu comércio eram devidos ao pai. Se um testamento era feito por algum estranho em seu favor, o legado era recebido, não por ele, mas pelo pai. Por aí se explica o texto romano que proíbe a venda de pai para filho, pois estaria o pai vendendo para si mesmo.

"Vemos no antigo direito de Roma e de Atenas que o pai poderia vender o filho (Plutarco, Sólon, 13. Dionísio de Alicarnasso, II, 26. Gaio, I, 117, 132. Ulpiano, X, 1. Tito Lívio, XLI, 8. Festo, Deminutus, 5으. É que o pai podia dispor de toda a propriedade que estava na família e o filho era considerado como simples propriedade do pai, pois seu trabalho era fonte de renda para o pai e para a família. O pai poderia, pois, guardar para si mesmo esse instrumento de trabalho ou cedê-lo a outro, e denominava-se 'vender o filho'. Os textos que possuímos não nos esclarecem devidamente sobre a natureza de tal contrato de venda e sobre as reservas porventura nele contidas. $\mathrm{O}$ que parece certo é que o filho não ficava na condição de escravo do comprador e que o pai poderia estipular no contrato que o filho lhe seria revendido. Guardava seu poder sobre ele e, depois de recebê-lo de volta, poderia tornar a vendêlo.

“A Lei das XII Tábuas autorizou esta operação até três vezes, declarando, porém, que após essa tríplice operação de venda, o filho seria libertado do poder do pai (Ulpiano, Fragmenta, X, 1). (...) O crime cometido por um filho contra o pai não dava lugar a nenhuma ação na justiça da cidade. Se o filho submetido ao poder pátrio comete um crime, a ação é movida contra o pai. De toda a família, apenas o pai poderia comparecer perante os tribunais 
da cidade. A justiça para o filho, como para a mulher, não estava na cidade, porque se encontrava no lar. Seu juiz era o chefe da família, sentado como que num tribunal, em virtude de sua autoridade conjugal ou paterna, em nome da família, e sob os olhos das divindades domésticas. (...) Poderia condenar à morte, como o magistrado da cidade, nenhuma autoridade teria o direito de modificar a sua sentença. (...) Seria formar uma ideia falsa pensar que o pai tinha o direito absoluto de matar mulher e filhos. Ele era o juiz. Se condenava à morte, fazia-o apenas em virtude de seu direito de justiça. Como o pai de família submetia-se apenas ao julgamento da cidade, a mulher e o filho não podiam encontrar outro juiz além dele. No seio da família o pai era o único magistrado.

“A autoridade paterna não era, porém, um poder arbitrário, como os que derivam da força. Ela tinha seu princípio nas crenças que estavam no fundo das almas, e encontrava seus limites nessas mesmas crenças. Por exemplo, o pai tinha o direito de excluir o filho da família, mas sabia que se o fizesse, a família correria o risco de se extinguir, e os manes de seus antepassados cairiam no eterno esquecimento. Tinha o direito de adotar estranhos, mas a religião proibia fazê-lo, se tivesse filhos. Era proprietário único de seus bens, mas não tinha o direito de aliená-los. Podia repudiar a mulher, mas, para isso, era preciso que ousasse quebrar o laço religioso que o casamento havia estabelecido. Assim, a religião impunha ao pai tanto obrigações como direitos" 22 .

Não nos capacitaremos da importância da autoridade paterna nas cidades antigas se não atentarmos para o fato de que, contrariamente ao que vem sucedendo no Ocidente a partir da Revolução Francesa, ou seja, a transferência para o Estado de um sempre maior número de tarefas, e a correspondente publicização de institutos jurídicos anteriormente da esfera privada, na Antiguidade a formação das cidades, polis na Grécia, civitas em Roma, não se fez com diminuição da esfera de poder dos chefes de família, mas através de uma verdadeira “confederação" de famílias com antepassado comum, de modo que a cidade não era, como em nossa época se pretende, uma reunião de indivíduos, mas sim uma reunião de famílias 23.

Não se concebe, com essa perspectiva, a possibilidade de entender o poder do soberano da cidade, o rei ou basileus, como absoluto, mas simplesmente como o de alguém que é o líder, o primus inter pares, na assembleia dos chefes de família.

\footnotetext{
${ }^{22}$ Fustel de Coulanges, op.cit.p.98-103., estando entre parênteses no texto as fontes que Fustel de Coulanges cita em notas de rodapé.

${ }^{23}$ Fustel de Coulanges op.cit. p. 145.
} 
A autoridade do pai, no seio da família, era de fato e de direito absoluta, como se verificou no capítulo anterior; já a autoridade, que hoje se chamaria "pública", do "governo", do rei ou do soberano era autoridade limitada, mais moral do que militar e policial.

Entende-se, então, melhor por que a cidade nunca teve força para revogar o estabelecido na tradição, alterando de modo substancial a estrutura da família, regulando as relações entre os membros desta. Seu papel limitou-se sempre a reconhecer o que já existia e era consagrado pela religião doméstica e pela prática desde tempos imemoriais.

De modo que, poder-se-ia concluir, o poder do pai não foi uma expressão, em âmbito menor, do poder do rei na sociedade política, como somos levados a crer, raciocinando, em termos de Antiguidade, como o fazemos em nossa época.

Antes, sucedeu exatamente o contrário. É a análise percuciente de Hannah Arendt:

"Ao tentarem introduzir na teoria política a noção de autoridade, Platão e Aristóteles vão buscar na autoridade do pai, no seio da família, o seu modelo: Tanto Platão como Aristóteles, embora de modo bem diferente, foram obrigados a firmar-se em exemplos de relações humanas extraídos da administração doméstica e da vida familiar gregas, onde o chefe de família governa como um 'déspota', dominando indiscutivelmente sobre os membros de sua família e os escravos de sua casa. O déspota, ao contrário do rei, o 'basileus', que fora o líder dos chefes de família e como tal 'primus inter pares', era por definição investido no poder para exercer coerção. E, contudo, era exatamente essa característica que tornava o déspota inapto para fins políticos; seu poder para coagir era incompatível não somente com a liberdade de outros, mas também com sua própria liberdade" 24 .

Ao encontrar na célula familiar a autoridade absoluta do pai, tanto o autor da Política como o idealizador da República se viram a braços com um grave problema: transferir a estrutura do poder da família para a cidade, como expressão da autoridade, mas sem a fundamentação religiosa que o culto dos antepassados dava ao pater familias, e, ao mesmo tempo, erigir um sistema de governo absoluto, mas sem ferir o absolutismo do poder dos chefes em suas famílias respectivas. Talvez daí decorram as contradições flagrantes na República, ressalvada a genialidade de sua construção teórica, de um lado; o empirismo organizador a que se acaba relegando a teoria política na obra, por isso mesmo mais realista, da Política, de outro lado.

Sem procurarmos resolver o dilema, que nos conduziria longe demais do tema de nosso

\footnotetext{
${ }^{24}$ Hannah Arendt, Entre o Passado e o Futuro, 2. ed., São Paulo, Ed. Perspectiva, 1972, p. 143 e 144.
} 
estudo, deixamos, no entanto, aqui consignado o interesse para a teoria geral do Estado deste capítulo do direito civil, desde a Antiguidade25.

Outro não foi o intento de um Sólon, em Atenas, senão o de harmonizar poder paterno familiar e poder político. Diz-nos W. K. Lacey: “O chefe da casa ('oikos') é a cabeça da família, seu senhor ('kyrios'), seu governador, domina os escravos como seu amo, os filhos, como uma espécie de rei, a mulher, como um líder, com a diferença que ele ama os filhos, sua mulher o ama, e não há mudança, como na cidade"26.

E prossegue, explicando: "Sólon, no interesse de toda a comunidade, estava ansioso para manter o maior número possível de casas ('oikoi’) no Estado, capaz de manter o cidadão pronto para servir o Estado com sua pessoa e haveres. Na antiga Atenas, embora não 'nacionalizando' as casas ('oikoi'), procurava orientá-las para o serviço da cidade, do demo ou da frátria, antes que para o interesse dos cidadãos (pais de família) individualmente”27.

Na Grécia clássica, informa-nos Jean Gaudemet, “a família representa um elemento constitutivo da cidade. Nesse ponto, o direito antigo da Ática confirma as opiniões que professava Aristóteles sobre as relações entre família e 'polis'. (A cidade se forma com a federação das famílias, mas a transcende porque só ela dispõe de força suficiente para impor ao homem a virtude. Política 1252a.) A célula básica é a família no sentido estrito, criada pelo casamento, agrupando pai, mãe e filhos. É a casa ('oikos') ou o lar ('hestia'). Um grupo familial mais largo e que, por conseguinte, não postula mais a vida em comum é constituído pela 'anchisteia'. Ele reúne os descendentes de um mesmo trisavô, e se estende até os primos germanos. A 'anchisteia' exerce a vingança de sangue em caso de assassinato de um dos seus membros, constitui-se também num grupo sucessoral. A sucessão é transmitida entre os homens e, na sua falta, às mulheres. A 'syngeneis' é a reunião de parentes de um círculo ainda mais vasto, pois todos descendem de um antepassado comum, mas tal parentesco não tem mais aspecto jurídico"28.

A cidade colocou limites ao pátrio poder, quando as Leis de Sólon proibiram a venda dos filhos (Plutarco, Sólon, 23).

\footnotetext{
${ }^{25}$ V., por exemplo, Yves Simon, Filosofia do Governo Democrático, Rio de Janeiro, Ed. Agir, 1955: "a função paternal da autoridade" (p. 15 e s.); José Pedro Galvão de Souza, Inicia-ção à Teoria do Estado, 2. ed. São Paulo, Revista dos Tribunais, 1976: “formação da sociedade política" (p. 7 e s.).

26 W. K. Lacey, The Family in Classical Greece, London, Thomas and Hudson, 1968, p. 21.

27 W. K. Lacey, The Family in Classical Greece, London, Thomas and Hudson, 1968, p. 85 e 99.

28 Jean Gaudemet, Institutions de L'Antiquité, Paris, Recueil Sirey, 1967, p. 205. Mais especificamente sobre as relações entre família e cidade em Aristóteles, p. 200-1.
} 
Na Península Itálica, Roma, a partir da Lei das Doze Tábuas, como já se viu, limita a três vezes a oportunidade de vender o filho.

Mas, substancialmente, nem a polis grega nem a civitas romana ousaram tocar no pátrio poder, tal como vinha de tradição mais antiga, tal como estava estabelecido no direito costumeiro. Em Roma, os mores majorum, os costumes dos antepassados, expressavam-se em disposições de tempos imemoriais, regulando as principais instituições: o casamento, o divórcio, a vida conjugal, o pátrio poder, disposições estas que se consideravam estabelecidas pelo fundador de Roma, Rômulo, e depois por Numa, o primeiro rei e legislador.

O pátrio poder era estabelecido pelo costume, na Roma primitiva, porque "o costume era a fonte do Direito"29.

Seria no regime republicano que — por instâncias da plebe — o direito assumiria a forma escrita. A partir de então, o direito costumeiro e a lei escrita regulamentariam, por vezes de modo competitivo e até conflitivo, as relações entre pais e filhos na civitas do Lácio.

Veremos agora outra prova histórica da verdade da concepção do Institucionalismo de Maurice Hauriou em outro cenário histórico.

\section{EXEMPLIFICAÇÃO DO PAPEL DA INSTITUIÇÃO DESDE A IDADE MÉDIA ATÉ AS VÉSPERAS DA REVOLUÇÃO FRANCESA DE 1789}

Após a morte de Carlos Magno, seus descendentes partilharam seus vastos domínios (partilha de Verdun - 843) para pôr fim a suas dissensões. Isso abalou profundamente a unidade do Império.

Durante os séculos IX e X, os bárbaros normandos (dinamarqueses, suecos, noruegueses, chamados vikings ou "reis do mar") atacaram o norte da Europa. O sul voltava a sofrer incursões sarracenas.

A unidade, comprometida pelo Tratado de Verdun, agora desaparecia por completo: os frágeis elos que prendiam as províncias ao poder central se romperam. As comunicações eram dificílimas, o que levou os povos atacados pelos bárbaros a contar apenas com seus próprios recursos na luta pela sobrevivência.

Sob a liderança de seu chefe, o conde — pertencente a uma estirpe que tinha seu fundador no enviado de Carlos Magno, habituado a reger os negócios da região e a resolver as

29 Jean Gaudemet, Institutions de L'Antiquité, Paris, Recueil Sirey, 1967, p. 381. 
questões difíceis - , as vítimas das invasões procuravam os montes mais escarpados, as zonas ocultas dos pântanos ou marecage, para organizarem postos de defesa.

Como descreve Funck-Brentano, essa foi a origem dos feudos: a célula inicial foi a família, única instituição que permaneceu coesa, quando todas as outras instituições e o próprio Império Carolíngio soçobraram.

Em quase todos os pontos da Europa surgiam nesse momento núcleos de resistência. Cada um deles gravitava em torno de um chefe, como outrora, o pater familias de Roma e de Atenas, de autoridade incontestada30.

Que esse líder se chame Dom Pelayo, iniciando a reconquista espanhola, ou Hugo Capeto, projetando sua ação para além dos limites de seu feudo, até ser coroado rei da França, fundando a dinastia capetíngia, que reinará até a Revolução Francesa, no século XVIII, nós temos sempre o protótipo do homem de guerra, ocupado em defender suas terras e as de seus agregados.

A estirpe que liderou, através dos séculos IX e X, a reação contra os bárbaros e sarracenos veio a constituir a nobreza feudal, a classe dos suseranos. Os agregados que buscavam socorro junto aos nobres, e que, em troca, ocupavam-se do amanho da terra deram origem à plebe ou vassalos.

Régine Pernoud nos descreve as relações entre suserano e vassalo como baseadas na mútua prestação de serviços, garantida pela confiança recíproca (a palavra "feudo" vem de "fé", ou seja, "confiança").

Da família, pois, nasceu o feudo. Do feudo veio a surgir o reino, quando os senhores feudais sentiram a necessidade de ter um árbitro para suas contendas; no rei feudal se consubstanciava e personalizava a ideia de nação.

Eis como se institucionalizou o sistema de feudalismo.

Para ter uma ideia clara da importância do pátrio poder e da família na Era Medieval, é necessário lembrar que o Estado, tal como o conhecemos hoje, como única fonte do direito positivo, único aparelho com poder de exercer coação e aplicar sanções, como detentor da soberania da nação, falando em seu nome de modo incontrastável, não havia nessa época.

Daí o papel desempenhado pela família patriarcal, muito mais ampla que a atual, recebendo a denominação de "mesnada", "grei”, compreendendo não só os pais e os filhos,

\footnotetext{
${ }^{30}$ F. Funck-Brentano, Le Moyen Age, Paris, Ed. Hachette, s/d, p. 7. Seria, na terminologia de G. B. Vico, um ricorso ou um "refluxo" do ciclo percorrido pela civilização ocidental na Grécia e na Roma primitivas, passando novamente pela "fase heroica".
} 
como na família moderna, mas também os cônjuges e descendentes dos filhos, os domésticos e agregados, os irmãos mais novos do pater etc. Daí terem surgido as condições para o regime feudal, com a autoridade concentrada em patriarcas locais, ciosos de sua independência perante qualquer poder centralizador de um Estado. "Trata-se de um rei em miniatura, que 'reina' sobre seus filhos e agregados. Ele é chamado 'sire' (= senhor) e sua esposa recebe o título de 'dame' (= senhora), a família sendo uma pequena 'pátria' (= terra dos pais)"31. Uma semelhança notável com a estrutura da sociedade grega ou romana, antes da polis.

Régine Pernoud sublinha a semelhança entre a família na cidade-Estado e na época feudal: “A sociedade medieval era composta de famílias. O chefe da família, o varão - donde vem "barão" na hierarquia social, é o 'dominus', o senhor. Ele é o administrador dos bens a família, dos seus filhos e de sua mulher: a família vive através da personalidade do pai, cujo nome levam, simbolizando sua perpetuidade, através das gerações. O que importa não é o indivíduo mas a linhagem ('la lignée’). Daí a preponderância da vida privada sobre a vida pública. O direito de propriedade não era do indivíduo mas da família, o bem familiar, o solar, cujo usufruto é detido pelos membros dela, mas não podendo ser alienado pelo seu chefe"32.

É preciso ter presente tudo isso para entender as disposições do direito visigótico. “Abrangendo no seu conjunto as disposições da lei visigótica que se referem ao conteúdo do poder paternal, verifica-se que este poder, longe de ser o senhorio absoluto, pressupõe a consideração do interesse dos filhos.

É certo que, nos preceitos da 'lex antiqua' é a ideia de poder — 'potestas' — que sempre ocupa o primeiro plano, sendo a autoridade do pai olhada principalmente pelo lado do seu direito e a situação correlativa do filho como uma situação de sujeição, mas isto não significava que os visigodos tivessem da 'patria potestas' o mesmo conceito que corresponde a essa expressão no Direito Romano da Era Clássica, pois implica em deveres para com os filhos e em proteção de seus interesses (= 'cura erga filiorum utilitatem')”33.

A Lex Romana Visigothorum já fala claramente em um officium do pai para com o filho, isto é, um dever. O Fuero Real admite limitações do poder do pai e a Ley de las Siete Partidas, temendo uma identificação com o conceito romano clássico, define: "ligamiento de reverencia,

\footnotetext{
${ }^{31}$ Franz Funck-Brentano, Le Moyen Âge, Paris, Ed. Hachette, s/d, p. 6 e 7. V. tb. L'Ancien Régime, todo o v. 1, Ed. Arthème Fayard, 1936, p. 9-111.

32 Régine Pernoud, Lumière du Moyen Âge, Paris, Ed. Bernard Grasset, 1954, p. 12-16.

33 Paulo Merêa, O Poder Paternal na Legislação Visigótica, Boletim da Faculdade de Direito da Universidade de Coimbra, Coimbra, 1939, v. 15, p. 297 e s.
} 
e de subieción, e de castigamiento, que el padre debe a su hijo" (Partida IV, Tít. 17, Lei 3). "El castigamiento cruel" é punido com a perda do pátrio poder (Ibid., T. 18, L. 18).

Da tradição latina conservou-se o que vinha favorecer o filho, como o peculium.

A ideia de autoridade, pois, correspondia não à de um senhor absoluto, como no direito romano clássico, que privilegiava o indivíduo, mas à de um organizador, à de um coordenador das atividades, privilegiando o grupo familiar.

Tanto isso é verdade que, como ampliação dessa ideia de autoridade limitada, "temperada", se chega à ideia de "rei", papel social desempenhado pelo árbitro nas questões entre senhores feudais, como uma espécie de "pater familias maior": "O governo monárquico tira sua origem do governo paterno, a família serve de modelo para a nação. Como aquela tem um chefe, esta também tem um, que é o rei. Assim raciocinam os teóricos do poder real, até o século XVII"34.

E, às vésperas da Revolução Francesa, conta-nos F. Funck-Brentano, o rei de França enviava para a Bastilha um nobre acusado por sua mulher e filhos de débauche, quando ainda questões familiares eram questions d'État35.

\section{EXEMPLO DE APLICAÇÃO DO INSTITUCIONALISMO PELO LEGISLADOR BRASILEIRO}

Clóvis Beviláqua (1859-1944) soube harmonizar, na elaboração do Código Civil, as últimas conquistas da ciência do direito no final do século XIX com os problemas sociais que começavam a surgir no século XX.

Por formação, Clóvis, que em filosofia era um adepto da Escola do Recife, e em sociologia um evolucionista spenceriano, tenderia talvez para uma posição, no campo do direito, "spenceriana, mas sem conceber a evolução culminando no triunfo individualista; admirador de Augusto Comte, mas sem admitir a redução do plano da religião ao da ciência; naturalista sim, mas sem divinizar a natureza, ou sentir escrúpulo em usar a palavra 'Deus', substituída por 'natureza naturante' (sic!), foi, no seu ecletismo heterodoxo, um criador, capaz de abrir rumos novos às especulações filosóficas ou filosófico-jurídicas.

34 Bernard Basse, La Constitution de l'Ancienne France, Lib. St. Louis Liancourt, 1973, p. 182.

35 Franz Funck-Brentano, Légendes et Archives de la Bastille, Paris, Ed. Hachette, 1901, p. 13-46 e 264-7. V. tb., sobre a força do droit coutumier perante o droit écrit nacional, Adriano Cavanna, Storia del Diritto Moderno in Europa, Milano, Giuffrè Edit., 1979, p. 391-409. 
Entretanto, Clóvis nunca seria um purista, mas sim um eclético, sintetizando os ensinamentos de vários pensadores, sem os distorcer.

Isso ele recebeu da convivência intelectual com Tobias Barreto, mentor principal da Escola do Recife.

“A Escola do Recife não era um rígido conjunto de princípios, uma sistematização definida de ideias, mas sim uma orientação filosófica progressiva, que não impedia a cada um investigar por sua conta e ter ideias próprias, contanto que norteadas cientificamente" 36.

Acrescentemos uma qualidade científica: a de saber captar o sentido histórico da realidade brasileira. Realizaria Clóvis - o que raramente acontece — uma síntese entre o rigor técnico na conceituação, na sistemática do Código, e a velha praxis lusitana de levar à categoria de artigos de lei as instituições de fato existentes na sociedade brasileira.

A tarefa não era fácil se tivermos presente que o Brasil era (e talvez até hoje o é) uma “terra de contrastes", na feliz expressão de Roger Bastide37. Não era fácil legislar sabendo que os efeitos da lei se estenderiam a regiões mais diferenciadas do que hoje.

Conseguiu-o o jurista cearense, escapando à dicotomia país real e país legal, pois o Código de 1916/17 resultou quase que da transcrição integral do Projeto de Clóvis, e, para aquela época, dificilmente poderíamos ter tido algo de mais adaptado à nossa realidade.

Proclamada a República, o jurista cearense de Viçosa, Clóvis Beviláqua, professor da Faculdade de Direito do Recife, em 1899, veio desincumbir-se, no Rio de Janeiro, da tarefa de redigir um Projeto de Código Civil. Convidado pelo Ministro da Justiça, Epitácio Pessoa.

Sabedor da importância histórica da ideia de direito natural no Brasil, Clóvis jamais compartilharia as críticas barretinas, antes aceitá-las-ia na concepção de Hauriou38, dando ao termo um sentido que lembra a "natureza das coisas" de Demócrito, de Lucrécio e de Haeckel.

Um grande pensador da Escola do Recife que larga influência exerceu sobre Clóvis Beviláqua foi Sílvio Romero.

Antigo adepto do positivismo de Auguste Comte, Romero passou, após breve período kantiano, a se entu-siasmar por Herbert Spencer. Chegou a escrever contra o positivismo o ensaio

\footnotetext{
36 Clóvis Beviláqua, História da Faculdade de Direito do Recife, São Paulo, Ed. Livraria Francisco Alves, 1927, 2 volumes, v. 2, p. 121.

37 Roger Bastide, Brasil - Terra de Contrastes, São Paulo, 6. ed., Difusão Europeia do Livro, 1975.

${ }^{38}$ Com a diferença - que mostra a acuidade de espírito de Clóvis — que Hauriou associa sem mais jusnaturalismo e democracia e Clóvis prefere ser mais fiel à história, lembrando que Aristóteles construiu toda a doutrina do direito natural sob o domínio de Felipe da Macedônia (Beviláqua, Obra Filosófica — Filosofia Social e Jurídica, cit., p. 215).
} 
de 1894, Doutrina contra Doutrina: o Evolucionismo e o Positivismo na República do Brasil: "as exageradas pretensões do Positivismo", "os erros da classificação das ciências" e sobretudo "a subordinação da atividade espiritual ao dogma religioso".

Porém não para aí o trabalho intelectual de Sílvio Romero. Até se pode dizer que sua obra maior foi a que executou como sociólogo da literatura e do folclore brasileiro, em obras muito divulgadas, buscando compreender o povo brasileiro.

Foi com Sílvio Romero que Clóvis passou a se interessar pela psicologia do povo brasileiro, e por suas manifestações, o que facultaria o sentido de realidade, que faltou a muitos legisladores brasileiros, mas não ao autor do nosso Projeto de Código Civil.

Clóvis considerava que a concepção do direito reflete uma concepção do mundo, sob pena de ser o espírito vacilante, evolucionista em ciências naturais, metafísico em direito, fetichista em religião39.

A "concepção do mundo" de Clóvis não o levava a esquecer desse mesmo mundo, no caso, o Brasil, o país para o qual deveria servir como legislador. Eis por que motivo Clóvis nunca sacrificou a postulados desta ou daquela Escola o que estava patente na realidade brasileira, não cedendo, tanto quanto pôde, às injunções socioeconômicas do momento.

O que de tal conjuntura passou para o Código, como veremos adiante, seria menos por força de ser Clóvis um individualista convicto - o que ele claramente repudia40 - e mais pelos fatores que estudamos nos itens anteriores deste capítulo, e que se espelharam nas modificações introduzidas no Código para sua publicação.

Defendeu-se, já em 1927, Clóvis de uma acusação de individualismo, ao ressaltar que no Código "a propriedade não é um direito absoluto, sofre as limitações impostas pela vida em sociedade e pelos interesses coletivos" 41 .

Por ora, gostaríamos de dizer que o Projeto tentou sintetizar os dados da realidade jurídica e social brasileira, dando-lhe uma roupagem romanística, erigindo em conceitos do direito romano simples situações historicamente condicionadas. Assim, a importância da propriedade, da família para uma sociedade burguesa ainda patriarcalista foi elevada à condição mais nobre de "instituição

\footnotetext{
${ }^{39}$ Da Concepção do Direito como Refletora de uma Concepção do Mundo, in Obra Filosófica, cit., p. 3 e s.

40 “O Código Civil não é individualista nem socialista. Procura conciliar a liberdade, a iniciativa, a expansão do indivíduo, com as necessidades sociais, num justo equilíbrio” (op. cit., p. 199). Em grande parte a concepção de Clóvis prevalecerá, pela larga difusão dos seus Comentários ao Código Civil Brasileiro, no sentido de atenuar o inegável sabor individualista da letra da lei, por exemplo, em matéria de família, testamento, propriedade, frisando o sentido social de tais institutos no direito brasileiro tradicional.

${ }^{41}$ Op. cit., p. 200.
} 
de direito", de acordo com a técnica pandectística e com as definições do direito romano.

Vê-se então que a problemática levantada por um Código Civil, considerado "a Constituição do homem privado", era de tal amplitude e magnitude que mesmo Clóvis Beviláqua deveria sucumbir e se curvar aos interesses em jogo, sob pena de ver seu Projeto rejeitado totalmente. Suas afirmações de 1927 são indício, em nossa opinião, de um sentimento profundo de insatisfação com o que afinal tinha ajudado a fazer. Daí suas reiteradas afirmações de que o Código não era "individualista", o que se pode entender claramente: "gostaria que ele não fosse interpretado por tal diapasão, já que não pude fazê-lo de outro modo".

Era o conflito interno de um intelectual, formado em uma filosofia individualista em extremo, que não pode aceitá-la, com seu bom senso de jurista, e, além disso, de estudioso do direito brasileiro, tendo inclusive escrito Instituições dos Indígenas Brasileiros, preocupado com seu estado de marginalização cultural; Características do Direito Pátrio, em que, como bom discípulo de Sílvio Romero, estuda o povo brasileiro; Evolução do Direito de Família no Brasil de 1827 a 1927, onde se mostra profundo conhecedor da história do direito no Brasil no século XIX. Enfim, Clóvis Beviláqua, contemporâneo de Ruy Barbosa, foi mais voltado do que este para as características do Brasil, sem ter jamais padecido da anglofilia ou da americanofilia como aquele insigne jurista, a quem faltou o senso histórico que sobejou no cearense.

Beviláqua ele sofreu decisiva influência das correntes mais notáveis de sua época, dentre as quais cabe salientar a Escola das Pandectas, sobretudo em sua expressão alemã: Windscheid, Jhering, de certo modo Savigny (jovem).

Tercio Sampaio Ferraz Jr. mostra a inspiração wolffiana no seu caráter formal-dedutivo de sistema de direito42, com base no direito romano clássico, não tanto quanto à forma de produção das normas quanto no que respeita à ideia de "sistema" de direito, com instituições logicamente encadeadas, e claramente expressas em conceitos precisos, more mecanico.

Clóvis aprendeu a estimar os autores pandectistas pelo ensino marcadamente romanístico nas Faculdades tanto de São Paulo como do Recife, chegando a dizer: "O Direito é uma ciência romana, por excelência"43. Considera Jhering, autor do Espírito do Direito Romano, uma defesa da perenidade do direito romano, "o maior jurista do século XIX e do futuro"44.

\footnotetext{
42 A Ciência do Direito, São Paulo, Ed. Atlas, 1977, p. 30.

${ }^{43}$ Clóvis Beviláqua, Obra Filosófica. São Paulo, Ed. Grijalbo,1975, 2 volumes, v. 2, Filosofia Social e Jurídica, p. 73 , nota 2 .

44 Id., Juristas Filósofos, p. 105-6.
} 
Seus Comentários ao Código Civil estão cheios de citações de autores pandectistas, entremeados de lições dos juristas romanos.

Foi também devido à influência pandectista que Clóvis acolheu a ideia de uma "Parte Geral", englobando "pessoas", "bens" e "fatos", antes de estudar na "Parte Especial” os vários ramos do direito civil. Não se pode esquecer que o Code Napoléon não contém "Parte Geral", e que neste ponto pelo menos, como reconhece Wieacker, o modelo foi o alemão45.

\section{O INSTITUCIONALISMO PRESENTE NO CONCEITO DE PLURALIDADE DE ORDENAMENTOS JURÍDICOS NA ITÁLIA: SANTI ROMANO E O ESTADO DA CIDADE DO VATICANO.}

O jurista italiano Santi Romano (1875-1947) viria trazer uma enorme contribuição para a Teoria Geral do Direito: trata-se do inovador conceito de "ordenamento jurídico". A partir de Santi Romano, em 1918, não se estudam mais as normas jurídicas isoladas uma das outras, mas concatenadas em um conjunto, o "Ordenamento Jurídico", título de sua obra.

Também Romano discute a possibilidade da convivência de vários ordenamentos jurídicos em um mesmo território. Era o caminho para o reconhecimento na Itália contemporânea, por exemplo, além do direito emanado do Estado, de um Direito Canônico da Igreja Católica, instituição milenar, mais antiga que qualquer Estado europeu moderno,resolvendo sério conflito entre o Estado italiano e a Santa Sé, depois da invasão dos centenários Estados Pontifícios, que datavam de Constantino e Carlos Magno, pelas tropas de Giusepp Garibaldi, auxiliadas por Napoleão III, em 1870, suscitando a “Questão Romana”, que durou até 1929,com o Tratado de Latrão, que reconheceu o Estado da Cidade do Vaticano, como enclave no território itálico.

Além disso o laicismo, que se introduzira na Europa desde o Iluminismo e que servirá de base para o anticlericalismo laicista, não era compartilhado pelo povo italiano em geral, o qual permanecia majoritariamente católico, resolvendo seus problemas de anulação ou dispensa de laços impeditivos de casamento perante tribunais eclesiásticos regidos por um Código de Direito Canônico, então renovado e readaptado em 1910.

45 F. Wieacker, História del Derecho Privado de la Edad Moderna: “do B.G.B. influiu o sistema e 62 artigos dos 1807 do Código", p. 437, nota 20. 
Como dizer que o Direito Canônico, mais antigo que o ordenamento jurídico de qualquer nação europeia não teria sido direito?

Mas era o que se deduzia do monismo de Hans Kelsen, que, lembremos mais uma vez, só admitirá como direito a norma que emana do Estado, não admitindo outras fontes geradoras.

Em sentido oposto, Santi Romano muito antes constatara que "o direito, antes de ser norma e antes de se referir a uma relação ou a uma série de relações sociais, é organização, estrutura e instituição da própria sociedade." 46

Para ele, o princípio da teoria da norma está associado à sociedade, já que vivemos em um mundo regido por normas. Sejam estas sociais, jurídicas ou do próprio individuo, a norma está no controle da vida do ser humano, mesmo que o mundo pareça um lugar "livre". Esta teoria caracteriza o direito como um conjunto de normas e regras de conduta, ou seja, " $a$ experiência jurídica é uma experiência normativa".

Desta forma, as normas têm a função de influenciar o comportamento de grupos de pessoas para dirigir suas ações rumo a determinados objetivos, e não para interesses conflitantes. Assim, tem-se que a função do sistema normativo é a ordenação da sociedade.

Inicialmente, como estamos dizendo, esta teoria foi elaborada por Santi Romano, o qual postula que a ordem social não é dada pelas normas, mas sim pela instituição que as promulga.

Desta forma, Romano explica que existem três principais elementos para tal: o primeiro seria a sociedade, na qual o direito ganha a sua existência; em segundo lugar temos a ordem, que pode ser traduzida como a finalidade do direito; e por final, em terceiro, existe a organização a qual é o meio para realizar-se a ordem. Logo, para este autor, o direito existe para "organizar uma sociedade de modo ordenado", ou seja, de acordo com a finalidade dessa mesma sociedade.

Esta sociedade organizada e ordenada recebe o nome de instituição e é necessário constatar também que o processo de transição pelo qual uma sociedade sem organização passa para virar uma sociedade organizada é denominado de institucionalização.

Para Norberto Bobbio, numa linha de pensamento que retoma o postulado de Kelsen, as normas devem vir muito antes da instituição (sic!) e o processo de institucionalização deve ocorrer da seguinte forma: em primeiro lugar devem ser afixados os fins que a instituição deverá perseguir; em segundo, ser estabelecido os meios para alcançar

\footnotetext{
${ }^{46}$ Santi Romano," L"Ordinamento Giuridico"pag.27. BOBBIO, Norberto "Teoria da Norma Jurídica", p.25.
} 
este fim; e em terceiro a atribuição de funções específicas aos componentes do grupo. Todavia, o processo de institucionalização não pode andar separado da produção de regras de conduta, já que "se a instituição equivale ao ordenamento jurídico, ordenamento jurídico equivale a complexo de normas."

Por sua vez, a teoria de Romano conduziu a um aprofundamento da teoria da norma, já que a teoria da norma não era explicada de forma satisfatória. Antes dele, "a norma jurídica isolada era o único objeto de estudo do direito".

Agora, pode-se supor a existência de tantos ordenamentos jurídicos quantas instituições existam em determinado território.

Apesar do regime totalitário, e por definição monista, ou seja na Itália fascista, houve pensadores pluralistas, como Santi Romano que, paradoxalmente ,foram ouvidos pelas instâncias governamentais, como nunca governos ditos liberais aceitaram, admitindo no máximo uma "Lei de Garantias" de livre expressão, aplicável a qualquer associação cultural na península.

A independência política e jurídica do papado, com relação ao governo italiano, foi garantida por esse Tratado até os nossos dias. Eis uma vitória concreta do pluralismo jurídico.

Outra notável contribuição de Santi Romano é a noção de "espaço jurídico vazio". Nem sempre a ausência de dispositivo legal sobre determinada matéria constitui uma lacuna jurídica...Pode haver situações em que o legislador deixa voluntariamente espaço para o arbítrio individual do cidadão.

Assim leciona o mestre da Universidade de Palermo: "existem dois tipos de espaço: o espaço jurídico cheio, que é o ocupado pela norma jurídica e o espaço jurídico vazio, destinado a ser preenchido pelo indivíduo, se lhe aprouver.

Na raiz desse ponto de vista está a constatação da liberdade natural do homem como algo histórica e logicamente anterior à limitação trazida pela legislação." ${ }^{47}$

\section{CONCLUSÃO}

Concluindo, podemos dizer que poucos autores lançaram teorias com tão grande fundamento nas várias épocas históricas como o Institucionalismo de Hauriou. Foi lamentável que, tendo escrito antes do aparecimento dos regimes totalitários, foi tão pouco ouvido, a ponto

\footnotetext{
${ }^{47}$ Santi Romano. Lo StatoModerno e la sua Crisi, ensaio sobre o "espaço jurídico vazio".
} 
de constatarmos que a vitória da democracia se operou na Segunda Guerra Mundial graças a triunfos militares ,pois a onda de simpatia pelo totalitarismo se alastrara pela Europa e América Latina, com não poucas adesões de juristas. Infelizmente, Carl Schmitt não foi um caso isolado. Terminado o conflito, temos que honestamente constatar que, em pleno regime democrático, o Estado se tornou poderoso "Moloch"e o positivismo jurídico foi e ainda é a teoria mais utilizada nas Faculdades de Direito.

Há estudantes que sequer sabem da existência de outras visões do direito além da pirâmide de Kelsen, que lhes é apresentada como única visão científica do direito.

No entanto, todos os juristas sabem que essa teoria é redutora, retira o direito do campo da Ética e o transfere para o campo da Lógica e -o que é muito grave -da Lógica Formal, própria da Matemática. Daí tanto apego à letra da lei. Daí a diminuição do papel do intérprete, daí as injustiças decorrentes da abstenção do exame da realidade social concreta.

Este artigo se propõe trazer um subsídio para tantos juízes, promotores, advogados,professores e estudantes insatisfeitos com o atual de praticar o direito que Ulpiano definiu como "a arte do bom e do justo".

\section{NOTAS:}

${ }^{1}$ Maurice Hauriou. Teoria dell'Istituzione e della Fondazione, pag.13-14.

${ }^{2}$ Idem,ibidem, pag. 17 .

${ }^{3}$ Miguel Reale, Fundamentos do Direito, pag. 291.

4Gioele Solari, Socialismo e Diritto Privato, Milano, Ed. Giuffrè, 1980, p. 55.

5Tercio Sampaio Ferraz Jr., A Ciência do Direito, São Paulo, Ed. Atlas, 1977, p. 27-30.

6 Gioele Solari, Storicismo e Ditto Privato, p. 27 e s.

7Joseph De Maistre, Considérations sur la France, 20. ed., Paris, Ed. Vitte, 1924, p. 74.

8 Realmente,o Estado totalitário se torna mais possível de se concretizar onde forem destruídos os corpos sociais intermediários entre o indivíduo e o Estado, como a família, a escola particular, a empresa privada, a associação profissional autônoma, a igreja, o clube,etc.

9 Joseph De Maistre, Étude sur la Souveraineté, 4. ed., Lyon, Liv. E. Vitte, 1924, p. 96 e s.

10 Ibid., p. 103.

11 Contrato Social, cap. I.

12 José Pedro Galvão de Sousa, A Historicidade do Direito e a Elaboração Legislativa, São 
Paulo, edição do autor, 1970, p. 57-8.

13 Joseph De Maistre, Considérations sur la France, Lyon, Liv. Ed. Vitte, 1924.

14 Galvão de Sousa, José Pedro. A Historicidade do Direito e a Elaboração Legislativa, São Paulo, edição do autor (tese de livre-docência na Faculdade de Direito da USP), 1970.

15 José Pedro Galvão de Sousa, op. cit., p. 115.

16 Numa Dénis Fustel de Coulanges, La Cité Antique, Paris: Hachette .9. ed., , 1881, p. 93.

17 Fustel de Coulanges, op.cit. p. 96

18 Ibid., p. 58.

19 Ibid., p. 96.

20 Fustel de Coulanges, op.cit.p.98-103., estando entre parênteses no texto as fontes que Fustel de Coulanges cita em notas de rodapé.

21 Fustel de Coulanges op.cit. p. 145.

22 Hannah Arendt, Entre o Passado e o Futuro, 2. ed., São Paulo, Ed. Perspectiva, 1972, p. 143 e 144.

24 V., por exemplo, Yves Simon, Filosofia do Governo Democrático, Rio de Janeiro, Ed. Agir, 1955: "a função paternal da autoridade" (p. 15 e s.); José Pedro Galvão de Souza, Inicia-ção à Teoria do Estado, 2. ed. São Paulo, Revista dos Tribunais, 1976: "formação da sociedade política" (p. 7 e s.).

25 W. K. Lacey, The Family in Classical Greece, London, Thomas and Hudson, 1968, p. 21.

26 W. K. Lacey, The Family in Classical Greece, London, Thomas and Hudson, 1968, p. 85 e 99.

27 Jean Gaudemet, Institutions de L'Antiquité, Paris, Recueil Sirey, 1967, p. 205. Mais especificamente sobre as relações entre família e cidade em Aristóteles, p. 200-1.

28 Jean Gaudemet, Institutions de L'Antiquité, Paris, Recueil Sirey, 1967, p. 381.

29 F. Funck-Brentano, Le Moyen Age, Paris, Ed. Hachette, s/d, p. 7. Seria, na terminologia de G. B. Vico, um ricorso ou um "refluxo" do ciclo percorrido pela civilização ocidental na Grécia e na Roma primitivas, passando novamente pela "fase heroica".

30 Franz Funck-Brentano, Le Moyen Âge, Paris, Ed. Hachette, s/d, p. 6 e 7. V. tb. L'Ancien Régime, todo o v. 1, Ed. Arthème Fayard, 1936, p. 9-111. 
31Régine Pernoud, Lumière du Moyen Âge, Paris, Ed. Bernard Grasset, 1954, p. 12-16.

32 Paulo Merêa, O Poder Paternal na Legislação Visigótica, Boletim da Faculdade de Direito da Universidade de Coimbra, Coimbra, 1939, v. 15, p. 297 e s.

33 Bernard Basse, La Constitution de l'Ancienne France, Lib. St. Louis Liancourt, 1973, p. 182.

34Franz Funck-Brentano, Légendes et Archives de la Bastille, Paris, Ed. Hachette, 1901, p. 1346 e 264-7. V. tb., sobre a força do droit coutumier perante o droit écrit nacional, Adriano Cavanna, Storia del Diritto Moderno in Europa, Milano, Giuffrè Edit., 1979, p. 391-409.

35 Clóvis Beviláqua, História da Faculdade de Direito do Recife, São Paulo, Ed. Livraria Francisco Alves, 1927, 2 volumes, v. 2, p. 121.

36 Roger Bastide, Brasil - Terra de Contrastes, São Paulo, 6. ed., Difusão Europeia do Livro, 1975.

37 Com a diferença - que mostra a acuidade de espírito de Clóvis - que Hauriou associa sem mais jusnaturalismo e democracia e Clóvis prefere ser mais fiel à história, lembrando que Aristóteles construiu toda a doutrina do direito natural sob o domínio de Felipe da Macedônia (Beviláqua, Obra Filosófica - Filosofia Social e Jurídica, cit., p. 215).

38Da Concepção do Direito como Refletora de uma Concepção do Mundo, in Obra Filosófica, cit., p. 3 e s.

39 “O Código Civil não é individualista nem socialista. Procura conciliar a liberdade, a iniciativa, a expansão do indivíduo, com as necessidades sociais, num justo equilíbrio" (op. cit., p. 199). Em grande parte a concepção de Clóvis prevalecerá, pela larga difusão dos seus Comentários ao Código Civil Brasileiro, no sentido de atenuar o inegável sabor individualista da letra da lei, por exemplo, em matéria de família, testamento, propriedade, frisando o sentido social de tais institutos no direito brasileiro tradicional.

40 Op. cit., p. 200.

41 A Ciência do Direito, São Paulo, Ed. Atlas, 1977, p. 30.

42 Clóvis Beviláqua, Obra Filosófica. São Paulo, Ed. Grijalbo,1975, 2 volumes, v. 2, Filosofia Social e Jurídica, p. 73, nota 2.

43 Id., Juristas Filósofos, p. 105-6.

44 F. Wieacker, História del Derecho Privado de la Edad Moderna: "do B.G.B. influiu o sistema e 62 artigos dos 1807 do Código", p. 437, nota 20. 
${ }^{45}$ Santi Romano," L"Ordinamento Giuridico"pag.27. BOBBIO, Norberto "Teoria da Norma Jurídica", p.25.

${ }^{46}$ Santi Romano. Lo StatoModerno e la sua Crisi, ensaio sobre o "espaço jurídico vazio".

\section{BIBLIOGRAFIA}

ARENDT, Hannah (1972). Entre o Passado e o Futuro. Tradução Mauro W. Barbosa de Almeida. São Paulo, Ed. Perspectiva, $2^{\text {a }}$ edição.

BASSE, Bernard (1973). La Constitution de l'Ancienne France. Liancourt, Librérie Saint Louis..

BASTIDE, Roger (1975). Brasil : Terra de Contrastes. Tradução de Maria Isaura Pereira de Queiro. São Paulo, Editora Difusão Europeia do Livro, $6^{\text {a }}$ Edição.

BEVILAQUA Clóvis(1975). Obra Filosófica. São Paulo, Editora Grijalbo, 2 vols.

BEVILAQUA, Clóvis(1927) História da Faculdade de Direito do Recife, São Paulo, Ed. Livraria Francisco Alves, 2 volumes, v. 2, p. 121.

BEVILAQUA, Clóvis(1930). Cotas a algumas idéias de Maurice Hauriou. Ensaio inserido na obra Linhas e Perfis Jurídicos. Rio de Janeiro, Editora Freitas Bastos.

BOBBIO, Norberto (1958). "Teoria della Norma Giuridica". Turim, Editora G.

Giappichelli.

BOBBIO, Norberto (1960). "Teoria dell'Ordinamento Giuridico". Turim, Editora G.

Giappichelli,

DE CICCO, Cláudio (2017). História do Direito e do Pensamento Jurídico. São Paulo, Editora Saraiva, $8^{a}$ edição.

DE MAISTRE, Joseph (1924). Considérations sur la France, Lyon, Editora Emmanuel Vitte, 20. Edição.

DE MAISTRE, Joseph. (1924). Étude sur la Souveraineté. Lyon, Liv. E. Vitte, 4. Edição.

FASSÒ, Guido (1970). Storia della Filosofia del Diritto. Bolonha, Editora Il Mulino, 3 vols.

FERRAZ JR. Tercio Sampaio (1977).A Ciência do Direito, São Paulo, Ed. Atlas.

FUNCK-BRENTANO, Frantz (1902). Légendes et Archives de la Bastille, Paris, Ed. Hachette.

FUNCK-BRENTANO, Frantz(1903). Le Moyen Age, Paris, Ed. Hachette. 
FUSTEL DE COULANGES, Numa Dénis (1881). La Cité Antique, Paris, Editora Hachette, $9^{\text {a }}$.edição.

GAUDEMET, Jean(1967). Institutions de L'Antiquité, Paris, Recueil Sirey.

HAURIOU, Maurice (1967).Teoria dell'Istituzione e della Fondazione.Tradução de Widar Cesarini Sforza. Milão Editora Giuffrè.

KELSEN, Hans (1949). Teoria General del Derecho y del Estado.Tradução de Eduardo Garcia Maynez. México, Imprenta Universitaria.

LACEY, W. K. (1968). The Family in Classical Greece, Londres, Editora Thomas and Hudson.

MER̂̂EA, Paulo (1939) O Poder Paternal na Legislação Visigótica, in Boletim da Faculdade de Direito da Universidade de Coimbra, Coimbra, v. 15, p. 297 e seguintes.

PERNOUD, Régine(1954).. Lumière du Moyen Âge, Paris, Ed. Bernard Grasset.

REALE, Miguel ( 2014). Fundamentos do Direito, Ribeirão Preto, Editora Migalhas, $4^{\text {a }}$ edição.

REALE, Miguel (1976) A Filosofia em São Paulo, 2. ed., São Paulo, Ed. Saraiva.

ROMERO Sílvio (1969) Obra Filosófica, São Paulo, Liv. José Olympio Editora/EDUSP.

ROMANO, Santi (1951).L'Ordinamento Giuridico. Florença, Editora Sansoni.

ROMANO, Santi.(1969) Lo Stato Moderno e la sua Crisi: Saggi di Diritto Costituzionale. Milão, Editora Giuffrè.

SIMON, Yves ( 1955) Filosofia do Governo Democrático, Rio de Janeiro, Editora Agir.

SOLARI, Gioele (1940) Storicismo e Ditto Privato. Turim. Ed.G. Giappichelli.

SOLARI, Gioele (1980) Socialismo e Diritto Privato, Milano, Ed. Giuffrè.

SOUSA, José Pedro Galvão de (1976) Iniciação à Teoria do Estado, São Paulo, Revista dos Tribunais, 2. Edição.

VON GIERKE,Otto(2008) Les Théories Politiques du Moyen Âge. Tradução de Jean de Pange. Paris, Edições Dalloz.

VON SAVIGNY, Friedrich Carl(2006) De la Vocations de Notre Temps pour la Législation et la Science du Droit. Tradução de Alfred Dufour. Presses Universitaires de France.

WIEACKER, Franz (1957) História del Derecho Privado de la Edad Moderna. Tradução de Francisco Fernandez Jardón. Madrí, Editora Aguilar. 
Quaestio Iuris

Trabalho recebido em 17 de julho de 2019

Aceito em 31 de maio de 2020 